\title{
Stage IIA Ovarian Cancer AJCC V6 and v7
}

National Cancer Institute

\section{Source}

National Cancer Institute. Stage IIA Ovarian Cancer A/CC V6 and v7. NCI Thesaurus. Code C5223.

Stage IIA includes: T2a, N0, M0. T2a: Extension and/or implants on uterus and/or tube(s). No malignant cells in ascites or peritoneal washings. N0: No regional lymph node metastasis. M0: No distant metastasis. (AJCC 6th and 7th eds.) 